\title{
Patterns Change of Awareness Process, Evaluation, and Regulation on Mathematics Student
}

\author{
Dwi Purnomo ${ }^{a}$, Susilo Bektia \\ aDepartment of Mathematics Education Institute of Teacher Training and Education \\ Budi Utomo Malang, INDONESIA
}

\begin{abstract}
This paper describe the change patterns in the process of awareness, evaluation, and regulation of mathematics students in solving mathematical problems. The patterns of change is reveled done by observation of the emergence of activity and indicators awareness, evaluation, and regulation of students. Student metacognition activities and indicators are outlined in 5 activities with 30 indicators of awareness process, 5 activities with 23 indicators of evaluation process, and 4 activities with 19 indicators of regulation process. The subjects of the study were students of mathematics education who had taken Differential Calculus and subjects were given mathematical problems. Mathematical problem solving is done through think-aloud. In addition to think-aloud research subjects were given metacognition questionnaires, observed using observation sheets, and interviews. The data include student work, think-aloud, metacognition questionnaire, interview, and observation were analyzed using fixed comparison method. The result show that the change pattern of awareness, evaluation, and regulation processes of mathematics students were categorized into complete sequenced metacognition process, complete unsequenced metacognition and incomplete metacognition.
\end{abstract}

\section{KEYWORDS}

Componen of Metacognition, Pattern, Complete Sequenced, Complete Unsequenced, Incomplete
ARTICLE HISTORY

Received 15 May 2017

Revised 10 July 2017

Accepted 2 September 2017

\section{Introduction}

Metacognition is a part of cognition. One's cognition consists of knowledge and cognition processes. Knowledge consists of factual, conceptual, procedural, metacognition. The process of cognition consists of remembering, understanding, application, analysis, evaluation, and creating, (Anderson \& Kratwohl, 2001). In relation to the metacognition processes, Davidson \& Stenberg (1988) and Yoong (2007) state that metacognition is important for problem solving during the learning process. In another way, metacognition is also important to know one's thinking process during problem solving (Cromley, 2005).

\section{CORRESPONDENCE D. Purnomo $\square$ dwi2purnomo@yahoo.co.id}

\section{(c) 2017 D. Purnomo \& S. Bekti}

Open Access terms of the Creative Commons Attribution 4.0 International License apply. The license permits unrestricted use, distribution, and reproduction in any medium, on the condition that users give exact credit to the original author(s) and the source, provide a link to the Creative Commons license, and indicate if they made any changes. (http://creativecommons.org/licenses/by/4.0/) 
The Government of the Republic of Indonesia through the regulation of Minister of Education and Culture of the Republic of Indonesia number 54 and 69 of 2013, and the Regulation of the Minister of Education and Culture of the Republic of Indonesia number 24 of 2016 has established metacognition as the ability to be mastered by students. Therefore, teachers need to understand well about metacognition knowledge, especially the process of metacognition thinking of students in order to provide input and direction so that students are able to master the knowledge of metacognition.

When a person does metacognition, there are three important components he performs, namely awareness, evaluation, and regulation (Wilson \& Clarke 2002, 2004; Magiera \& Zawojewski, 2011). Awareness is a state in which a person is aware of what he thinks. It shows him thinking about what is known (tasks, specific knowledge, relevant mathematical knowledge, or problem-solving strategies), thinking about where he is in the problem-solving process, thinking about what else remains to be done or what can be done. Evaluation is a situation in which a person conducts a study of the decision-making process in a mathematical thinking activity that indicates the person is thinking about the effectiveness and limitations of his or her mind, the effectiveness of his chosen strategy, the assessment of the outcomes, the assessment of his or her difficulty, the assessment of his progress, his ability, or his understanding. Regulation is a state in which a person thinks about his strategic planning, goal setting, and the choice of solving strategies in problem solving.

Research on metacognition in relation to problem solving has been done by several researchers. These studies include metacognition and its effectiveness, metacognition related to learning strategies, and metacognition in relation to learning evaluations. Metacognition research and its effectiveness were conducted by Wilson (1997), Desoete et al. (2001), Wilson \& Clarke (2002, 2004), and Biryukov (2003). Metacognition research related to learning strategy is done by Lioe et al. (2006). Magiera \& Zawojewski (2011), Kuzle (2011), and Mariam \& Idrus (2013). Metacognition research in conjunction with instructional evaluation was performed by Karan \& Irizary (2011), In'am et al. (2012), Sengul \& Katranci (2012), Jayapraba (2013), and Zainal \& Tajudin (2013).

Biryukov (2003) examined the effectiveness of learning with metacognition and found 3 important things. First, metacognition experience is important for students, because when students know how to apply the experience of metacognition it is possible that in solving the problem will work. Second, metacognition behavior demands to make a schematic model of the known and to form a coping strategy. Third, there is a difference between students' assumptions in understanding combinatoric problems based on the questionnaire results with practice when solving a given combinatorial problem.

Metacognition research related to learning strategy (Lioe et al, 2006; Magiera \& Zawojewki, 2011; Kuzle, 2011; Mariam \& Idrus, 2013) summed up 4 important points. First, metacognition strategies in students through paired interactions can facilitate the learning process with the workings of couples in the class (Lioe et al., 2006). Second, process evaluation on metacognition is the most common type identified during problem solving, followed by regulation, and then awareness (Magiera \& Zawojewski, 2011). Third, affective behaviors, such as persistence, confidence, interest, and frustration often occur during problem 
solving activities so that the constant interaction between cognition, metacognitive behavior and strategy is essential to successful problem solving. Students can develop cognitive actions and strategies to make cognitive progress, while at the same time it is important to monitor the cognitive processes that occur (Kuzle, 2011). Fourth, metacognition allows students to choose the right strategy to use because there is no way to solve the word problem (Mariam \& Idrus, 2013).

Metacognition research in relation to the evaluation process concludes two important points. First, metacognition strategies can be used to enhance students' metacognition skills, including those involving self-evaluation of learning strengths and weaknesses, and taking into account three types of awareness: declarative knowledge, procedural knowledge, and conditional knowledge (Karan \& Irizary, 2011). Second, the level of metacognition approach of students to solve algebraic problems consisting of awareness, cognition strategy, planning and review aspects in general are in good category, while overall under good category (In'am et al., 2012). Some other research conclusions about metacognition in relation to the evaluation process conclude two things. First, the improvement of metacognition skills that are key factors in creating and maintaining successful learning can also improve learning improvements. In terms of problem solving there are two important things: the development of specific strategies with special rules and mental process improvement for approaches that can be used in making rules or formulas (Sengul \& Katranci, 2012). Second, metacognition instruction can increase metacognition awareness and in it can develop a positive attitude toward learning. In addition, students' academic achievement may increase if a planned teaching strategy is metacognized. Students should be taught how to develop and realize strategy. Teachers must increase their students' metacognition awareness to improve their learning abilities. The more students know effective learning strategies, the greater their metacognition awareness and their high grade achievements (Jayapraba, 2013).

Zainal \& Tajudin who also conducted research on metacognition in relation to the evaluation process and concluded that the metacognition that occurs in students occurs in 4 phases, namely the orientation phase, organizational phase, implementation phase and attestation phase. Metacognition process is an important aspect to determine success in solving math problems rather than routine. Highly performing students demonstrate better metacognition processes than moderate and low-ability students. Highability students have the ability to orient problem based on their interpretation of the given problem. Moderate and low-ability students have difficulty in problem orientation and do not attempt to make a strategic plan in solving nonroutine problems (Zaenal \& Tajudin, 2013).

Referring to the results of research Wilson \& Clarke (2002, 2004) and Magiera \& Zawojewski (2011) researchers have conducted preliminary research. The preliminary research was conducted on mathematics education students who have taken Differential Calculus courses. The material chosen in the preliminary study is Calculus, because Calculus is the starting material given to the students of Mathematics Education Department and contains the basic materials that will be studied at the next level. Another thing that underlies the research done to students because according to Piaget students cognitive 
development level is at formal operational stage. Characteristics of the formal operational stage is the ability to think abstractly, reason logically, and draw conclusions from available information, and can understand things that are abstract.

This study chose the calculus material because it is based on the statement of Sabella \& Redish (1996) and Marrongelle (2007). Sabella \& Redish (1996) describes "for most students in mathematics, science, and engineering, calculus is the entry-point to undergraduate mathematics. Because of its importance in its calculus, it has a lot of research studies in the student understanding of calculus". On the other hand, Marrongelle (2007) states"the importance of research on the concepts of calculus and students' understanding of calculus concepts lays a foundation for their future study of advanced mathematics, science, and engineering courses. The idea of change-both how things change and the rate at which things change-plays a very important role in the students' conceptualizations of calculus concepts. Students must understand the concept of rate of change in order to understand the derivatives and differential equations. Furthermore, students must understand the idea of total change to understand the integrals. Finally, the students must understand the relationship between the rate of change and the total change in order to understand the relationship between derivatives and integrals outlined by the fundamental theorem of calculus.

Preliminary research results indicate the existence of activities that occur in the process of awareness, evaluation and regulation as long as students solve the problem. The awareness process generates 5 activities, evaluation process with 5 activities and regulation prosess with 4 activities. Awareness activities include students rethinking what is known from a given mathematical problem (A1), rethinking questions in mathematical problems and relating them to similar problems that have been previously obtained and resolved (A2), rethinking about something that has not been resolved at a time earlier when solving the given mathematical problem (A3), rethinking the next step to be done to solve the given mathematical problem (A4), and rethinking the description of the answer to the given mathematical problem (A5). Evaluation activities include the students rethinking the way in which to solve the given mathematical problem (E1), rethinking the sequence and steps to be taken when solving the given mathematical problem (E2), re-examining the completed answers to mathematical problems (E3), rethinking whether or not the answer to the completed mathematical problem has been solved (E4), and rethinking the failure done in answering the mathematical problems given in the previous way (E5). Regulation activities include students rethinking and making plans to quickly solve the given mathematical problem (R1), rethinking the different ways in which to answer the given mathematical problem (R2), rethinking what to do next after completing the mathematical problem (R3), and rethink how to change the way in solving a given mathematical problem (R4). Activities in the process of awareness, evaluation, and regulation are outlined in the indicators. The awareness process includes 30 indicators, the evaluation process includes 23 indicators, and the regulation process includes 19 indicators. These indicators can be seen in Table 2. (Purnomo, 2016a, 2016b).

The activities and indicators that appear in the process of awareness, evaluation, and regulation are not yet known how the pattern of change, 
whether the pattern of linear awareness, evaluation, and regulation, or cyclically intact, or cyclical but partial or perhaps irregular still no research and theory that can provide answers. Therefore, finding patterns, sequences, and characteristics of activities in the process of awareness, evaluation, and regulation should be sought. Thus, further research is needed, especially in relation to the specific characteristics of indicators of each activity awareness, evaluation, and regulation.

\section{Metacognition}

Metacognition in English is expressed by the term metacognition derived from two words namely meta and cognition. The meta term is Greek petá and is translated with after, beyond, with, adjacent which is a prefix used to denote an abstraction of a concept. (Wikipedia, Free Encyclopedia, 2008). While cognition, according to the Encyclopedia is derived from the Latin cognoscere, which means knowing (to know) and recognize (to recognize). Cognition, also known as introductory symptoms, is "the act or process of knowing, including both awareness and judgment (Koentjoyo, 2009: 1).

According to Zahmeister \& Neyberg (1982) cognition is a mental activity associated with perception, mind, memory, and information processing that enables a person to acquire knowledge, solve problems, and plan for the future, or all psychological processes related to how individuals learn, Observe, imagine, estimate, assess and think about the environment. During the process, metacognition can be associated with problem-solving activities, knowledge, cognition processes and strategies used during the learning process.

Metacognition was originally a term used by Flavell in 1976 in developmental psychology research. According to him, metacognition consists of knowledge, experience and regulation. Knowledge is related to the cognition that can be used to control the thinking process. Experience is applied to control cognition activity in achieving learning objectives. Regulation is called metacognition experience which in the process involves the use of metacognition strategies or metacognition rules.

Flavell (1976) further explains that metacognition serves as an important element and contributes to successful problem solving, enabling one to identify and work strategically. According to Flavell, metacognition is divided into two different aspects of knowledge metacognition and awareness of individuals in the process of cognition called metacognition experience. Experience includes planning, selecting and monitoring cognitive strategies; Evaluate or examine the results of such activities; And revise plans and strategies.

Metacognition is often also often described as knowledge of metacognition and regulation or metacognition monitoring (Veenman, 2012). Knowledge metacognition is a person's knowledge and ability to perform tasks, strategies chosen in completing tasks. Regulation or metacognition monitoring involves activities related to the planning, monitoring, evaluation of a person and the process of cognition in order to better regulate the processes occurring in the future.

Metacognition as a process has four important aspects. According to Baker \& Brown (1984) the important aspects of metacognition are self-regulation, planning, evaluation, and monitoring. Wellman (1985) states that metacognition 
as a form of cognition or a two-tier process of thinking involves controlling cognitive activity so that metacognition can be thought of as thinking about one's own thinking or one's knowledge of cognition.

In addition to having four aspects, metacognition according to Schoenfeld (1992) is a process of thinking someone about what he has thought and metacognition occurs through the interaction between three important aspects of knowledge of thought processes, control or self-regulation, and beliefs and intuition. Interaction is very important because knowledge of the cognition process can help and organize matters relating to the process of selecting strategies to improve future cognitive skills. The process of metacognition according to Schoenfeld includes the ability to ask questions and answer questions about a subject, topic and subject matter, the length of time students spend on certain topics, strategies, methods and tactics used, the levels students are learning, student mistakes, and Revise a plan that will be done.

Livingstone (1997) defines metacognition as thinking about thinking. In other words metacognition is the ability to think someone about what he thinks, so that the object metacognition is the process of thinking that happens to yourself. Biryukov (2003) suggests that metacognition is a conjecture of one's thinking about his thoughts which includes knowledge, skills and experience. Knowledge in the form of awareness about what is known, skills shaped awareness about something done, and experience is an awareness about the ability of cognition owned.

Davidson \& Sternberg (1998), states that metacognition serves as an important element and contributes to problem-solving success that allows individuals to identify and work strategically. Metacognition is also called by another term metamemory (Friedrichs \& Hoyt, 1976). Schoenfeld then introduced the concept of control as a medium that plays a role in the cognitive strategy intended for resource allocation. Matlin (1998) states that metacognition is our knowledge, awareness, and control of our cognitive processes. Metacognition according to Matlin is a knowledge related to awareness and cognitive processes. Tan (2003) states that metacognition is thoughtfulness that refers to thinking about self-thinking, self-examining and processing information and how to process information effectively. Lioe et al. (2003) states that metacognition is the awareness of a person about the process of cognition and independence to achieve certain goals. Metacognition arises in problem solving whose components are attitudes, skills, concepts, and processes.

Mokos \& Kafoussi (2013) states, metacognition is a person's ability to monitor and control himself against something he knows. During the process of learning mathematics is important about the existence of a research process of metacognition of students during the move to solve problems that are more focused on problem-solving areas related to mathematics.

Based on several opinions and definitions that have been stated above can be identified the main points of understanding about metacognition. (1) metacognition is a person's ability and included in the group of cognition, (2) metacognition is the ability to realize, know, the process of cognition that occurs in self, metacognition is the ability to direct the process of cognition that occurs in yourself. (3) metacognition is the ability to learn how to learn should be done which includes the process of planning, monitoring, and evaluation, 
metacognition is a high-level thinking activity because its activities are able to control the thinking process that is going on yourself, (5) metacognition associated with the process of thinking about thinking of finding the right strategy for solving problems, and (6) metacognition skills are crucial in solving mathematical problems, so they need to be improved. To improve metacognition skills required the awareness that must be possessed by students in every step of their thinking.

\section{Metacognition Components}

During the process of metacognition according to Wilson (1997) occurs the process of awareness, evaluation, and regulation and its process during metacognition as illustrated in Figure 1.

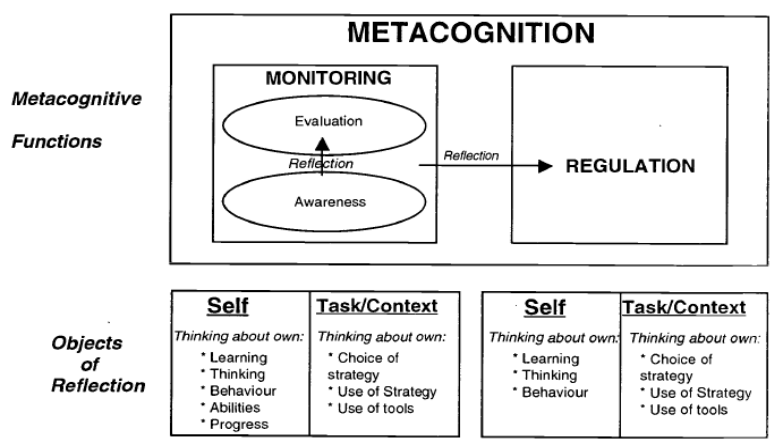

Figure 1 Sequence of metacognition components according to Wilson (1997)

Illustration in Figure 1 shows that the process of metacognition changes from awareness to evaluation occurs through a process of reflection. Awareness and evaluation referred to as monitoring activities change into regulation also through reflection. Reflection is a process of mediation where awareness can be changed into evaluation and evaluation can be changed into regulation in metacognitive thinking process. The reflections made from awareness to evaluation are related to the student's self and the assigned task. Reflection on the student self is related to thinking about the learning process, what he thinks, the behavior, abilities, and progress he has. While the reflection relating to the tasks is to think about the selection of strategies undertaken, the use of strategies and the use of tools during the learning process it has. After awareness and evaluation process occurs regulation process. The regulation process begins with reflection. Reflections before the regulation process also include reflections on students' self and the tasks assigned. Reflection on students' self is related to thinking about learning process, thinking, and student behavior. While the reflection relating to the task is to think about the selection of strategies, the use of strategies and tools that students have used during reflection of these tasks.

The awareness, evaluation, and regulation described in by Wilson \& Clarke (2004) are the basic concepts in research conducted and used to explain the pattern and characteristics of changes in the process of awarness, evaluation, and regulation of metacognition of students in solving mathematical problems. More specifically, metacognition component indicators proposed by 
Wilson \& Clarke (2004) were further developed by Magiera \& Zawojewski (2011). Magiera \& Zawojewski (2011) provides a description of the metacognition component and states that awareness is a state in which a person is aware of what he thinks or what others think. This state shows him thinking (a) what is known (task, specific knowledge, relevant mathematical knowledge, or problemsolving strategy), (b) thinking about where he is in the problem-solving process, (c) thinking about what else still needs Done or (d) what can be done. Evaluation is a situation in which a person conducts a study of the decision-making process in a mathematical thinking activity that indicates the person is thinking about (a) the effectiveness and limitations of his mind, (b) the effectiveness of the strategy he chooses, (c) the assessment of the outcome (d) , And (e) an assessment of its progress, ability, or understanding. Regulation is a state in which a person thinks about (a) his strategic planning, (b) goal setting, and (c) the choice of his problem-solving strategy.

Magiera \& Zawojewski (2011) statement on the description of types of metacognition activity as shown in Table 1.

Table 1 Metacognition activities by Magiera and Zawojewski

\begin{tabular}{|l|l|}
\hline \multicolumn{1}{|c|}{ Code Descrption } & \multicolumn{1}{c|}{ Description } \\
\hline Awareness Metacognition & $\begin{array}{l}\text { Statements made about the mathematical thinking of a person or } \\
\text { other person, indicating a thought about what is known by } \\
\text { someone?, where a person is solving problem solving?, what is } \\
\text { needed to do?, what has been done?, and what can be done? }\end{array}$ \\
\hline Evaluation metacognition & $\begin{array}{l}\text { Decisions made about the mathematical mind of a person or } \\
\text { others that indicate the effectiveness and limitation of thinking, } \\
\text { the effectiveness of the chosen strategy, the assessment of the } \\
\text { results, the assessment of progress, and the ability or } \\
\text { understanding. }\end{array}$ \\
\hline Regulation metacognitiomn & $\begin{array}{l}\text { Statements made about one's mathematical thinking or others } \\
\text { indicating a strategic planning process, setting goals, choosing a } \\
\text { strategy for problem solving. }\end{array}$ \\
\hline
\end{tabular}

Based on the results of preliminary studies that are associated with previous research and theoretical studies have been determined activity and indicator of each activity that the size of the emergence of process awareness, evaluation, and regulation. Activity and indicator of each activity which become the measure of awareness, evaluation, and regulation process are seen in Table 2 below.

Table 2 The Finding Activities and Indicators of Awareness, Evaluation, dan Regulation

\begin{tabular}{|c|c|c|}
\hline \multicolumn{3}{|r|}{ Awareness } \\
\hline No & Activitiy & Indicators \\
\hline 1 & $\begin{array}{l}\text { Rethink of what is } \\
\text { known of } \\
\text { mathematics } \\
\text { problem given (A1). }\end{array}$ & $\begin{array}{l}\text { The subject of the study: } \\
\text { 1. Read the given problem repeatedly and give marks at the words } \\
\text { which are regarded as the key-words (A1.1). } \\
\text { 2. Note the important cases of problems by underlining the words } \\
\text { which are regarded as the key-words (A1.2). } \\
\text { 3. Check the figure in the problem and represent the length and } \\
\text { width of the figure as variable } x \text { and } y \text { (A1.3). } \\
\text { 4. Read the table of problem and note it as the known case and } \\
\text { differentiate the volume for the field as part of problem known } \\
\text { (A1.4). } \\
\text { 5ake an important note and conclude known cases as the } \\
\text { requirement to determine the way of solving the problem given } \\
\text { (A1.5). }\end{array}$ \\
\hline
\end{tabular}




\begin{tabular}{|c|c|c|}
\hline & & $\begin{array}{l}\text { 6. Make a relationship between the cases known in the problem } \\
\text { and each questions which will be answered at the problem given } \\
\text { (A1.6). }\end{array}$ \\
\hline 2. & $\begin{array}{l}\text { Rethink the } \\
\text { questions of } \\
\text { mathematics } \\
\text { problems and } \\
\text { similar problems } \\
\text { which are finished } \\
\text { before (A2) }\end{array}$ & $\begin{array}{l}\text { The subject of the study: } \\
\text { 1. Read each question repeatedly and relate them to the previous } \\
\text { questions of problems as known cases (A2.1). } \\
\text { 2. Give marks at the words which are regarded as the key-words } \\
\text { and each questions and conclude cases asked in problems }(\mathrm{A} 2.2) \text {. } \\
\text { 3. Make relationship question (a) in the problem relating to the } \\
\text { area of rectangular. The relationship between area (L) and } \\
\text { length and width is } L=x y \text { or } L=5 x y \text { depends on the assumption } \\
\text { done for the length and width which are assumed before (A2.3). } \\
\text { 4ake relationship between the length of available barbed wire } \\
\text { (s) on the problem and the fanced stable in the form of equation } \\
S=x+6 y \text { or } s=5 x+6 y \text {. Since the length of barbed wire is } 240 \\
\text { meters, there are two equations can be written: } 240=x+6 y \text { or } \\
240=5 x+6 y \text { (A2.4). } \\
\text { 5. State the area of rectangular at the problem known as one } \\
\text { function consisting of long and wide variable known as area } \\
\text { function variable (A2.5). } \\
\text { 6. Change the function of rectangular area on the problem given as } \\
\text { one function variable by determining the maximum requirement } \\
\text { of a field area (A2.6). } \\
\text { 7. Conclude the cases asked in the problem based the note made } \\
\text { (A2.7). }\end{array}$ \\
\hline 3. & $\begin{array}{l}\text { Rethink of cases } \\
\text { which have not } \\
\text { been finished in the } \\
\text { last time yet when } \\
\text { finishing } \\
\text { mathematics } \\
\text { problem given (A3). }\end{array}$ & $\begin{array}{l}\text { The subject of the study: } \\
\text { 1. Make the relationship between the length of barbed wire and } \\
\text { wired stable part as equation } 240=x+6 y \text { or } 240=5 x+6 y(\mathrm{~A} 3.1) \text {. } \\
\text { 2. State the area of stable in form of one changer function as } L=x y \\
\text { into } L=x(240-6 x)(\mathrm{A} 3.1) \text {. } \\
\text { 3. State the area of stable in the form of one changes function as } \\
L=5 x y \text { into } L=5(240-6 y / 5)_{y}(\mathrm{~A} 3.3) \text {. } \\
\text { 4. Do the substitution of area function in one changer and } \\
\text { determine downward (derivative) of the function (A3.4). } \\
\text { 5. Write downward of one changer function and determine the } \\
\text { requirement of maximum and minimum value of a function as } \\
d L / d x=0 \text { or } d L / d y=O \text { (A3.5). }\end{array}$ \\
\hline 4. & $\begin{array}{l}\text { Rethink the next } \\
\text { step to do to finish } \\
\text { mathematics } \\
\text { problem given (A4) }\end{array}$ & $\begin{array}{l}\text { The Subject of the study: } \\
\text { 1. Looking aback cases known in the problem (A4.1). } \\
\text { 2. Chose the way used to do the problem given based on the } \\
\text { knowledge got before (A4.2). } \\
\text { 3. Determine variable value decided after down warding the area } \\
\text { function stated in one changer function (A4.3). } \\
\text { 4. Do variable substitution which has got into the previous } \\
\text { function, i.e. } 240=x+6 y \text { or } 240=5 x+6 y(\mathrm{~A} 4.4) \text {. } \\
\text { 5. Find out the whole stable area and each stable as the answer of } \\
\text { the problem given (A4.5). } \\
\text { 6. Reread table at the problem given to check the truth of the } \\
\text { answers got (A4.6). } \\
\text { 7. Write the area comparation of each stable and the amount of } \\
\text { goats (A4.7). } \\
\text { 8. Write the fee of stable building material and the fee of weekly } \\
\text { operational as stated in table of problem given (A4.8). }\end{array}$ \\
\hline 5. & $\begin{array}{l}\text { Rethink the } \\
\text { explanation of the } \\
\text { answers of } \\
\text { mathematics } \\
\text { problem given (A5). }\end{array}$ & $\begin{array}{l}\text { The subject of the study: } \\
\text { 1. Reread the answers of the problem to make known the order and } \\
\text { systematically answers of problem as being asked and required } \\
\text { at the questions (a), (b), and (c) (A5.1). } \\
\text { 2. Try to use another way to answer the problem which has not } \\
\text { done before (A5.2). } \\
\text { 3. Use the new way repeatedly and check the cases known in the } \\
\text { problem (A5.3). } \\
\text { 4. Compare the answers explanation between one way and the }\end{array}$ \\
\hline
\end{tabular}




\begin{tabular}{|c|c|c|}
\hline & & other which has been done before (A5.4). \\
\hline \multicolumn{3}{|r|}{ Evaluation } \\
\hline No. & Activities & Indicators \\
\hline 1. & $\begin{array}{l}\text { Rethink the way } \\
\text { used to finish } \\
\text { mathematics } \\
\text { problem given (E1). }\end{array}$ & $\begin{array}{l}\text { The subject of the study: } \\
\text { 1. Compare the result of each way done in answering the questions } \\
\text { at the problem given (E1.1). } \\
\text { 2. Mark the important things at the ways and steps used to solve } \\
\text { the problem (E1.2). } \\
\text { 3. Note the important cases at the difference between the used to } \\
\text { solve the problem given (E1.3). } \\
\text { 4. Make the relationship between cases known and the ways used } \\
\text { to finish problem (E1.4). }\end{array}$ \\
\hline 2. & $\begin{array}{l}\text { Rethink of the } \\
\text { order of steps to do } \\
\text { at the time } \\
\text { finishing } \\
\text { mathematics } \\
\text { problem given } \\
\text { (E2). }\end{array}$ & $\begin{array}{l}\text { The subject of the study: } \\
\text { 1. Recheck the relationship between the cases known and cases } \\
\text { asked in the problem (E2.1). } \\
\text { 2. Check the explanation of the answers written based on in the } \\
\text { ways done (E2.2). } \\
\text { 3. Recheck the relationship writing between the length of wire } \\
\text { available at the problem given and part of the fence which is } \\
\text { fenced (S2.3). } \\
\text { 4. Read the table and make an order of the amount of goats in each } \\
\text { stable with the area of each stable (E2.4). } \\
\text { 5. Mark the important cases on the steps of answering problem } \\
\text { done (E2.5). }\end{array}$ \\
\hline 3. & $\begin{array}{l}\text { Check the answers } \\
\text { of mathematics } \\
\text { problems finished } \\
\text { (E3). }\end{array}$ & $\begin{array}{l}\text { The subject of the study: } \\
\text { 1. Check maximum and minimum requirement of one changer } \\
\text { function based on the area formula written before (E3.1). } \\
\text { 2. Recount the length and width of the whole stable and each of the } \\
\text { stable at the problem given (E3.2). } \\
\text { 3. Recount the comparation between the area of the stable and the } \\
\text { amount of goats in each stable (E3.3). } \\
\text { 4. Recount the amount of the building stable material (E3.4). } \\
\text { 5. Recount the operational fee of the whole stables weekly (E3.5). } \\
\text { 6. Conclude question answers thoroughly (E3.6). }\end{array}$ \\
\hline 4. & $\begin{array}{l}\text { Rethink of the } \\
\text { truth of the } \\
\text { mathematics } \\
\text { answers available } \\
\text { (E4). }\end{array}$ & $\begin{array}{l}\text { The subject of the study: } \\
\text { 1. Reread the question answers (a), (b), and (c) to make known } \\
\text { whether the answers written on the answer sheet are right or } \\
\text { not (E4.1). } \\
\text { 2. Make a relationship between answers obtained and each } \\
\text { problem given (E4.2). } \\
\text { 3. Correct the length and width of the stable obtained with the } \\
\text { length of the wire available (E4.3). } \\
\text { 4. Recount problem (b) and (c) by looking back table } 1 \text { on the } \\
\text { mathematics problem (E4.4). }\end{array}$ \\
\hline 5. & $\begin{array}{l}\text { Rethink the failure } \\
\text { done in answering } \\
\text { mathematics } \\
\text { problem given by } \\
\text { previous way (E5). }\end{array}$ & $\begin{array}{l}\text { The subject of the study: } \\
\text { 1. Reread the answers of each of the question to know the truth } \\
\text { value (E5.1). } \\
\text { 2. Recheck the answers about the requirement fill fulled maximum } \\
\text { and minimum value of the area of whole stable in the question } \\
\text { (a) (E5.2). } \\
\text { 3. Recheck question answers (b) about comparation between the } \\
\text { amount of stable and the area of the stable as the requirement at } \\
\text { figure (1) and table (1) on mathematics problem (E5.3). } \\
\text { 4. Recheck the answers (c) about total operational fee each week } \\
\text { and stable building fee as being required on table (1) on the } \\
\text { mathematics problem (E5.4). }\end{array}$ \\
\hline \multicolumn{3}{|r|}{ Regulation } \\
\hline No. & Activitiies & Indicators \\
\hline 1. & Rethink of making & The subject of the study: \\
\hline
\end{tabular}




\begin{tabular}{|c|c|c|}
\hline & $\begin{array}{l}\text { a plan to finish } \\
\text { mathematics } \\
\text { problem given soon } \\
\text { (R1). }\end{array}$ & $\begin{array}{l}\text { 1. Recheck the problem answer repeatedly before making } \\
\text { conclusion (R1.1). } \\
\text { 2. Decide the proper and easy way to answer problem questions } \\
\text { given (R1.2). } \\
\text { 3. Order the answers of each questions based on the requirement } \\
\text { known before (R1.3). } \\
\text { 4. Mark the failure in counting the problem answers given (R1.4). } \\
\text { 5. Reread table and figure in the problem given to determine the } \\
\text { easy and proper way used to answer the problem given (R1.5). }\end{array}$ \\
\hline 2. & $\begin{array}{l}\text { Rethink different } \\
\text { way used to answer } \\
\text { mathematics } \\
\text { problem given (R2). }\end{array}$ & $\begin{array}{l}\text { The subject of the study: } \\
\text { 1. Check the way used to answer the problem question (R2.1). } \\
\text { 2. Differentiate the way used to finish mathematics in problem } \\
\text { given (R2.2). } \\
\text { 3. Order the question answers of each question in the problem } \\
\text { given (R2.3). } \\
\text { 4. Use the easy way in answering questions to explain the answers } \\
\text { of each problem (R2.4). }\end{array}$ \\
\hline 3. & $\begin{array}{l}\text { Rethink of what } \\
\text { will do to start } \\
\text { answering } \\
\text { mathematics } \\
\text { problem (R3). }\end{array}$ & $\begin{array}{l}\text { The subject of the study: } \\
\text { 1. Reread the known cases in the problem given (R3.1). } \\
\text { 2. Check the countability of data at the table and figure with the } \\
\text { answer given in the problem given (R3.2). } \\
\text { 3. Determine and decide the easy way which can be used to answer } \\
\text { the problem given (R3.3). } \\
\text { 4. Determine the answer problem question by making relationship } \\
\text { between the known cases and asked (R3.4). }\end{array}$ \\
\hline 4. & $\begin{array}{l}\text { Rethink how to } \\
\text { change the way in } \\
\text { finishing } \\
\text { mathematics } \\
\text { problem given (R4). }\end{array}$ & $\begin{array}{l}\text { The subject of the study: } \\
\text { 1. Recheck the answers of problem questions given and compare } \\
\text { the questions to rectangular figure known (R4.1). } \\
\text { 2. Mark the important cases of the answers known (R4.2). } \\
\text { 3. Make a conclusion at the answers using the way done (R4.3). } \\
\text { 4. Check the answer difficulty level done (R4.4). } \\
\text { 5. Recheck the answers of the problems given at answer sheet of } \\
\text { the subject of the study (R4.5). } \\
\text { 6. Conclude each question answer (a), (b), and (c) of questions given } \\
\text { (R4.6). }\end{array}$ \\
\hline
\end{tabular}

\section{Research Methods}

The type of research conducted is descriptive qualitative so that the method used in the research is to analyze the qualitative data consisting of work, think-aloud, metacognition questionnaire, the results of observation and interview. The steps to get data are (1) to give Calculus problem to 23 students majoring in Department of Mathematics Education Institute of Teacher Training and Education Budi Utomo Malang who have taken Differential Calculus course. Calculus problems are questions about the application of a function derivative of a variable to determine the maximum or minimum area of an area. Problem as an instrument has been validated by mathematicians from the side of the concept and mathematics education experts from the side of the language it uses. (2) the research subjects solved this problem with think-aloud for 60 minutes. The researcher corrects students' work to classify them into high, moderate, and low-ability students categories. Interview activities are recorded in the form of video and audio for the metacognition process. (3) After the subject completes Calculus, the researcher gives a metacognition questionnaire in the form of 14 statements about metacognition and each statement given alternative answers "yes", "no" or "unsure". The statement in the questionnaire consists of six statements related to process awareness, 5 statements related to the evaluation process, and three statements related to the regulation process. If the research subject answers "yes" means 
metacognition arises, if it does not mean metacognition does not appear, and if the subject answered "unsure" the researcher followed up with the interview. (4) Researchers study video recordings and record the results in an observation sheet consisting of activities and indicators of awareness, evaluation, and regulation. On the observation sheet, the awareness process contains 5 activities with 30 indicators, the evaluation contains 5 indicators with 23 indicators, and the regulation contains 4 activities with 19 indicators. (5) conducting interviews, the interview aims to explore the emergence of activities and indicators of awareness, evaluation, and regulation. (6) research data obtained subsequently transcribed. Transcription is done after the researchers get the data needed in the study. The transcripts of data in this study are thought-aloud transcripts and interviews. (7) Conducting data reduction, data reduction is done by creating a core abstraction that summarizes the data, processes and statements that need to be maintained in order to remain within it. Compilation of data in units which are further categorized by coding. (8) data analysis, metacognition process analysis each research subject through each activity and indicator awareness, evaluation, and regulation. The analysis is done to describe the activity of thinking of research subject according to activity and indicator of every process awareness, evaluation, and regulation. (9) Data validation, data validation is done by triangulation technique and peer examination through discussion and research result seminar. (10) Summing up the results of the study. The conclusions were obtained by comparing work results, metacognition questionnaires, think-aloud transcripts, observations using observation sheets, and interview transcripts of each study subject.

\section{Results and Discussion}

Initial data of 23 research subjects who perform awareness, evaluation, and regulation obtained results as follows.

Table 3 Research Subjects Conducting Metacognition

\begin{tabular}{|l|l|c|}
\hline \multicolumn{1}{|c|}{ Category } & \multicolumn{1}{|c|}{ Description } & $\sum$ Subjek \\
\hline \multirow{2}{*}{$\begin{array}{l}\text { Metacognition } \\
\text { Components }\end{array}$} & Complete Sequenced Metacognition & 4 \\
\cline { 2 - 3 } Based on & Complete Unsequence Metacognition & 13 \\
\cline { 2 - 3 } Abilities & Incomplete Metacognition & 6 \\
\hline \multirow{3}{*}{ High Ability } & High Ability & 6 \\
\cline { 2 - 3 } & Medium Ability & 9 \\
\cline { 2 - 3 } & Low Ability & 2 \\
\cline { 2 - 3 } & Complete Sequenced Metacognition & 2 \\
\cline { 2 - 3 } & Complete Unsequence Metacognition & 2 \\
\hline \multirow{3}{*}{ Ledium Ability Ability } & Complete Sequenced Metacognition & 2 \\
\cline { 2 - 3 } & Complete Unsequence Metacognition & 6 \\
\cline { 2 - 3 } & Incomplete Metacognition & 1 \\
\cline { 2 - 3 } & Complete Sequenced Metacognition & 5 \\
\cline { 2 - 3 } & Complete Unsequence Metacognition & 3 \\
\hline
\end{tabular}

To provide an overview of changing patterns of metacognition process of mathematics students in solving mathematical problems, research presented data for 3 research subjects representing each pattern of change of awareness, evaluation and regulation. The exposure of the data was $\mathrm{S}-1$ for the subjects who conducted complete sequenced metacognition, S-3 subjects who did complete unsequenced metacognition, and S-5 subjects who did incomplete metacognition. 


\section{Research Results for S-1}

S-1 is the subject of research that conducts complete sequenced metacognition. Changes to the process awareness patterned A1, A2, A3, A4, and A5, changes in the process evaluation patterned E1, E2, E3, E4, and E5, and changes in regulation process patterned $\mathrm{R} 1, \mathrm{R} 2, \mathrm{R} 3$, and $\mathrm{R} 4$. The overall pattern of changes in the process of metacognition of students based on the emergence of activities and indicators on $\mathrm{S}-1$ began in the process of awarness, evaluation and regulation with the pattern $\mathrm{A} 1, \mathrm{~A} 2, \mathrm{~A} 3, \mathrm{~A} 4, \mathrm{~A} 5, \mathrm{E} 1, \mathrm{E} 2, \mathrm{E} 3, \mathrm{E} 4, \mathrm{E} 5, \mathrm{R} 1, \mathrm{R} 2$, R3, and R4. The pattern of change based on the emergence of each indicator that occurs in awareness, evaluation, and regulation for S-1 as shown in Figure 2.

Box A, E, and R illustrate the process of awareness, evaluation, and regulation. Large circles describe the activity and small circle in each big circle illustrating the indicator of each component of metacognition. The arrow direction indicates the order of change of each indicator on each activity. The change pattern starts from the red box in box $\mathrm{A}$ and ends in a red circle on the $\mathrm{R}$ box.

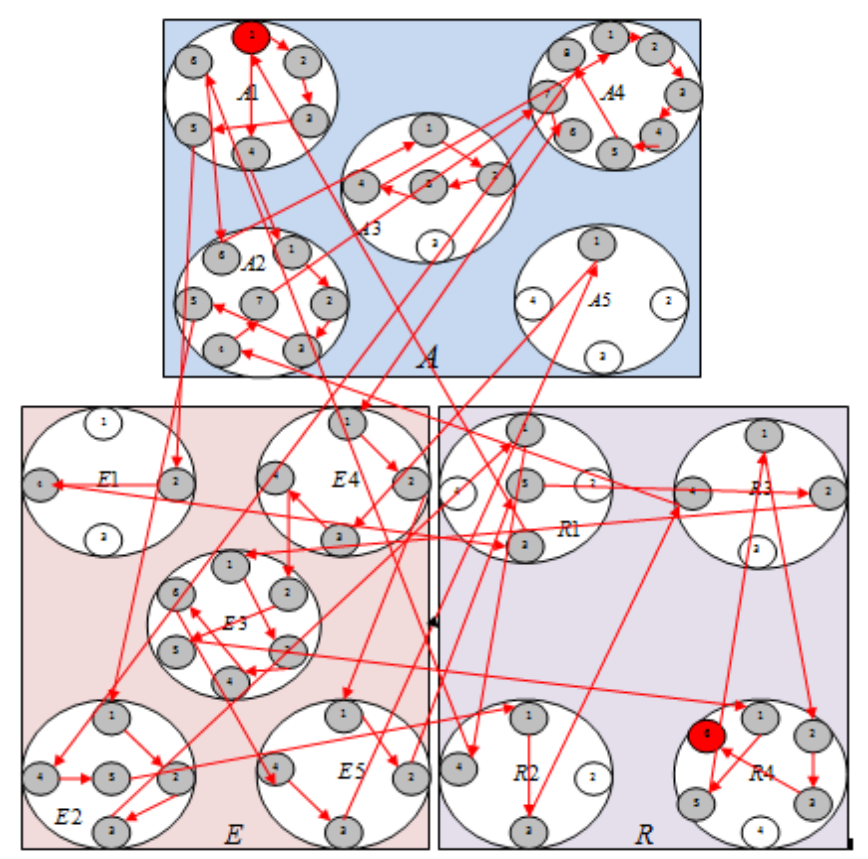

Figure 2 Complete Metacognition Change Pattern Ordered on S-1

Based on Figure 2, we can explain the sequence of patterns of metacognition process $\mathrm{S}-1$ in solving a mathematical problem that starts from a small red circle on rectangle A and ends in a small red circle on rectangle $\mathrm{R}$. The order of the change pattern is A1.1, A1.2, A1.3, A1.5, E1.2, E1.4, R1.3, A1.1, A1.4, A2.1, A2.2, A2. 3, A2.5, E2.1, E2.2, E2.3, R1.1, R2.4, A1.6, A2.6, E3.1, E3.2, 
E3.5, E3,4, A4.1, A4.2, A4.3, A4.4, A4.5, A4.8, E2.4, E2.5, R2.1, R2.3, R3.4, A2.4, A2. 7, A4.7, A4.6, E4.1, E4.2, E5.1, E5.2, R1.5, R3.2, E3.1, E3.3, E3.4, E3.6, E5.4, A5.1, E4.3, E4.4, E3.2, E3.5, R4.1, R4.5, R3.1, R4.2, R4.3, R4.6.

\section{Research Results for S-3}

S-3 is a subject of research that performs complete unsequenced matacognition. Pattern of metacognition changes in S-3 in order of awareness, evaluation, and regulation. The change awareness process is patterned A1, A2, A3, A5, A4. The change evaluation process is patterned E2, E1, E3, E4, E5. The regulation change process is patterned $R 1, \mathrm{R} 3$. $\mathrm{R} 2$, and $\mathrm{R} 4$. The overall pattern of changes in the process of awareness, evaluation, and regulation on S-3 is patterned A1, A2, A3, A5, A4, E2, E1, E3, E4, E5, R1, R3, R2, and R4.

The pattern of changes in awareness, evaluation, and regulation on S-3 as shown in Figure 3.

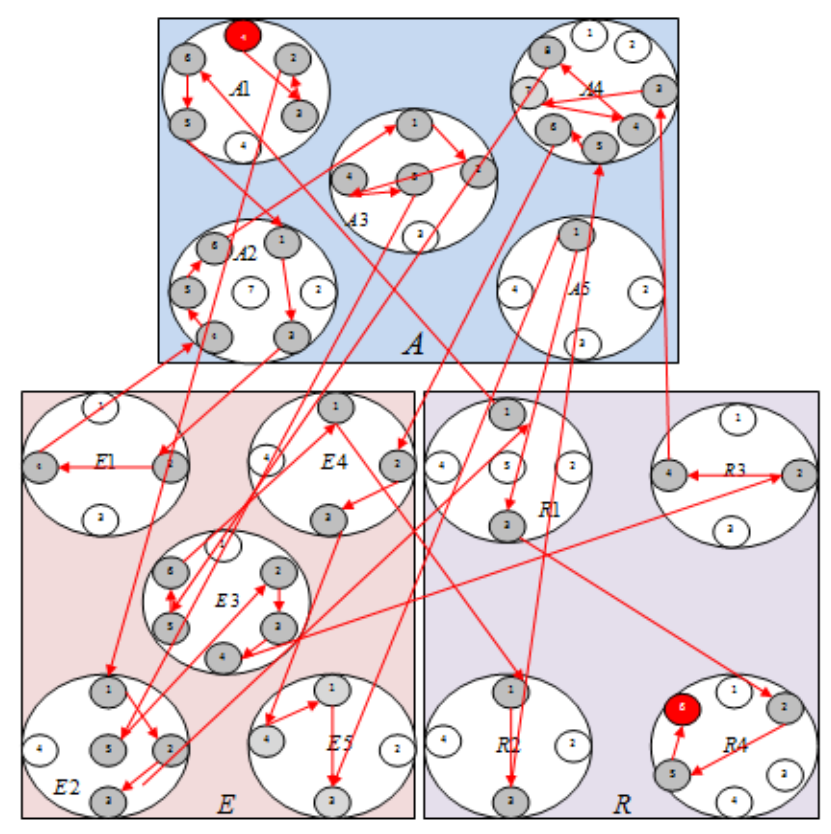

Figure 3 Patterns of Underscored Metacognition Changes in S-3

Based on Figure 3, we can explain the sequence of pattern changes of metacognition process S-3 in solving the mathematical problem that starts from a small red circle on rectang $\mathrm{A}$ and ends in a small red circle on rectangle $\mathrm{R}$. The order of the change pattern is A1.1, A1. 3, A1.2, E2.1, E2.2, E2.3, R1.1, A1.6, A1.5, A2.1.A2.3, E1.2, E1.4, A2.4, A2.5, A2.6, A3.1, A3.2, A3.4, A3.5, E2.5, E3.2, E.3.3, E3.4, R3.2, R3.4, A4. 3, A4.7, A4.4, A4.8, E3.5, E3.6, E4.1, R2.1, R2.3, A4.5, A4.6, E4.2, E4.3, E5.4, E5.1, E5.3, A5.1, R1.3, R4.2, R4.5, R.4.6.

\section{Research Results for S-5}

S-5 is the subject of research that performs incomplete metacognition. The pattern of metacognition changes is A1, A3, A2, A4, A5 in process awareness, 
E1, E2, E3, E4 on process evaluation, and R1, R3, R2, R4 on regulation process. The overall pattern of complete metacognition change not sorted is A1, A3, A2, A4, A5, E1, E2, E3, E4, R1, R3, R2, and R4.

The pattern of changes occur in awareness, evaluation, and regulation on S-5 as shown in Figure 4

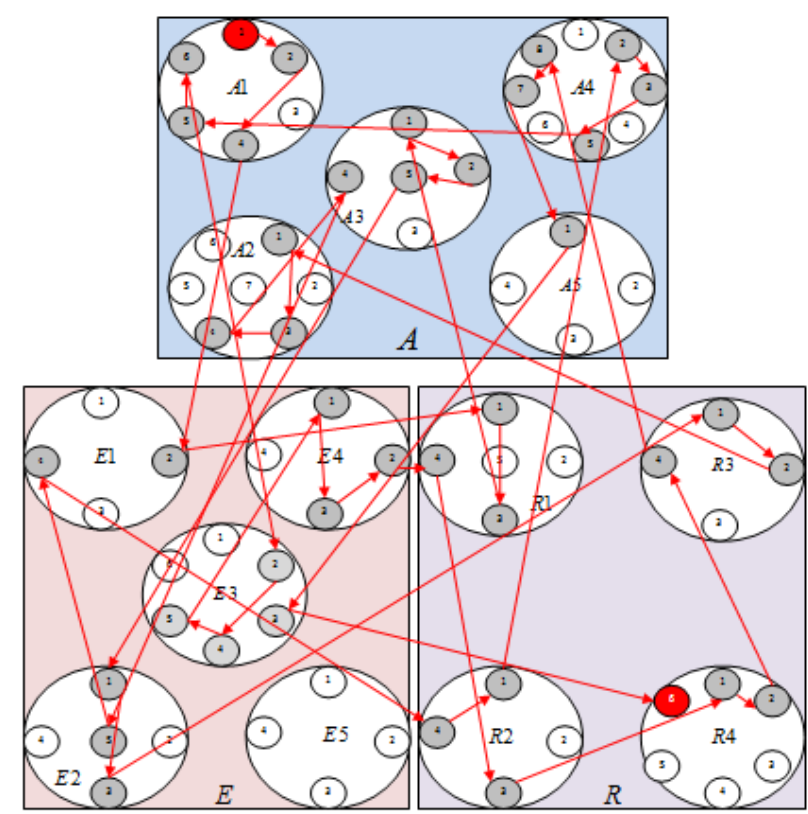

Figure 4 Pattern of Incomplete Metacognition Changes on S-5

According to Figure 4, it can be explained the sequence of patterns of metacognition process changes S-5 in solving the mathematical problem that starts from a small red circle on rectangle A and ends in a small red circle on the rectangle $\mathrm{R}$. The order of the pattern is A1.1, A1. 2, A1.4, E1.2, R1.1, R1.3, E3.1, E3.2, E3.5, E2.1, E2.3, R3.1, R3.2, A2.1, A2.3, A2.4, A3.1, E2.5, E1.4, R2.4, R2.1, A4.2, A4.3, A4.4, A1.5, A1.6, E3. 2, E3.4, E3.5, E4.1, E4.3, E4.2, R1.4, R2.3, R4.1, R4.2, R3.4, A4.8, A4.7, A5.1, E3.3, R4.1.

Captions figure 2, 3 and 4

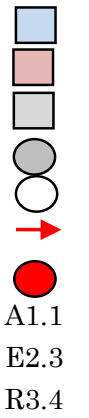

: Awareness as metacognition component

Evaluation as metacognition component

Regulation as metacognition component

: The indicator that appears

Indicators that do not appear

: The direction of the metacognition change pattern

: The beginning and end patterns of metacognition change

A1.1 : The emergence of the 1st indicator of the 1st activity in the awareness process

E2.3 : The emergence of the 3rd indicator of the 2 nd activity in the evaluation process

R3.4

: The emergence of the 4 th indicator of the 3 rd activity on the regulation process, etc. 


\section{Conclusions and Suggestions}

Based on data analysis, it can be concluded that the change pattern of awareness, evaluation, and regulation of mathematics students in solving mathematical problems can be categorized into complete sequenced metacognition, complete unsequnced metacognition, and incomplete metacognition. Each process of awareness, evaluation, and regulation in each category has a different pattern.

Complete sequenced metacognition in awareness process patterned the students rethinking what is known from the mathematical problem, rethinking the question in mathematical problems and relating it to similar problems that have been resolved before, rethinking about something that has not been resolved in the past when solving the problem Mathematically, rethinking the next step that must be done to solve a given mathematical problem, rethinking the description of the answer to the mathematical problem given. In the evaluation process the student rethinks the method used in solving the mathematical problem, rethinking the sequence of steps to be taken when solving the mathematical problem, re-examining the mathematical problems, which have been resolved, rethinking the correct answers to mathematical problems, and rethinking failure done in answering mathematical problems in the previous way. In the regulation process, the students rethink their plans to solve mathematical problems, rethink the different ways in which to solve mathematical problems, to rethink what to do next in answering mathematical problems, and to think about changing the way in solving mathematical problems.

Complete unsequenced metacognition in awareness process patterned the students rethinking what is known from the mathematical problem, rethinking the question in mathematical problems and relating it to similar problems that have been resolved in the past, rethinking about something that has not been resolved in the past when solving a mathematical problem, rethink the next step that must be done to solve a given mathematical problem, rethink the description of the answer to the mathematical problem given. In the evaluation process the student rethinks the sequence and the steps to be taken when solving the mathematical problem, rethinking the method used in solving the mathematical problem, re-examining the mathematical problem, rethinking the answer to the mathematical problem, and rethinking the failure made In answering mathematical problems in the previous way. In the regulation process the students rethink their plans to solve mathematical problems, rethink what to do next in answering mathematical problems, to rethink the different ways in which mathematical problems are solved, and to rethink how to solve mathematical problems.

Incomplete metacognition in awareness process patterned the students rethinking what is known from the mathematical problem, rethinking something that has not been resolved in the past while solving the mathematical problem, rethinking the question in mathematical problems and relating it to similar problems that have been resolved. Beforehand, rethink the next step to be done to solve the mathematical problem, and rethink the answers to the given mathematical problems given. In the evaluation process the students rethink the methods used in solving mathematical problems, rethinking the 
steps to be taken when solving the mathematical problems, re-examining the results of mathematical problems, reconsidering whether or not answers to mathematical problems have been resolved. In the process of regulation, the students rethink the plans to solve the mathematical problems immediately, to rethink what to do next in starting to answer the mathematical problems, to rethink the different ways in which to solve mathematical problems, and to rethink how to solve mathematical problems.

Based on the research findings, the suggestions put forward for further research are (1) Findings and research results obtained occurred in the group of private college students. These findings can be followed up on the public college students as research subjects and relate to the type of questions used, the variations and origins of the student school or the time of execution during the metacognition process. (2) The complete sequenced, complete unsequnced and incomplete metacognition are observed in the process of awarness, evaluation and regulation. In another case, further research is needed on how metacognition pattern and change between each process of awarness, evaluation and regulation. (3) The indicator that arises in metacognition process is during student solve the problem of Calculus Differential. Further research that can be done is how the indicator that arises if the problem is given other than Differential Calculus. Is there a different?

\section{Disclosure statement}

No potential conflict of interest was reported by the authors.

\section{Notes on contributors}

Dwi Purnomo, Doctor of Mathematics Education in Department of Mathematics Education Institute of Teacher Training and Education Budi Utomo Malang-Indonesia.

Susilo Bekti, Doctor of Mathematics Education in Department of Mathematics Education Institute of Teacher Training and Education Budi Utomo Malang-Indonesia

\section{Refrences}

Anderson, L.W. \& Krathwohl, D.R. (2001). A Taxonomy for learning, teaching, and assessing (A Revision of Bloom's taxonomy of educational objectives). New York: Addision Wesley Longman, Inc.

Baker, L. \& Brown, A. L. (1984). Metacognitive skills and reading. In Douglas J. Hacker, John Dunlosky and Arthur C. Graesser (Eds.) Handbook of metacognition in eucation. (pp. 7-25). New York: Routledge.

Biryukov, P. (2003). Metacognitive aspects of solving combinatorics problem kaye College of Education. Direct access:http://www.cimt.org.uk/journal-/biryukov.pdf.

Cromley, J.G. (2005). Metacognition, cognitive strategy instruction, and reading in adult literacy. Direct access: http://www.ncsall.net/index :html@id=782.htm.

Davidson J. E., Deuser R. \& Sternberg R. J. (1994). The Role of Metacognition in problem solving. In J. Metcalfe and A. R. Shimamura (Eds.), Metacognition: knowing about knowing (pp. 207226). Cambridge, MA: MIT Press.

Davidson, J. E. \& Sternberg, R. J. (1998). Smart problem solving: How metacognition helps. In D. J. Hacker., J. Dunlosky, A. C. Graesser (Eds.), Metacognition in educational theory and practice (pp. 47-68). Mahweh, NJ: Lawrence Erlbaum Associates. 
Desoete, A., Roeyers, H. \& Buysse, A. (2001). Metacognition and mathematical problem solving in grade 3. Journal of Learning Disabilities; Sep-Oct 2001; 34, 5; Academic Research Library.pp 435. Direct access:http://www.fi.uu.nl

Flavell, J. (1976). Metacognitive aspects of problem solving. in L. Resnick (Ed), In the Natrure of Intelligence. Direct access:http://www.library.edu.

In'am, A., Sa'ad, N. \& Ghani, S.A. (2012).A Metacognitive approach to solving Algebra problems. International Journal of Independent Research and Studies. University Pendidikan Sultan Idris, Malaysia. Direct access:http://www. aiars.org/ijirs...20120195.pdf.

Jayapraba, G. (2013). Metacognitive instruction and cooperative learning strategi for Ppomoting insightful learning in Science. International Journal on New Trends in Education and Their Implications. Direct access:http://www:ijonte.org.

Karan, E. P. \& Irizarry, J. (2011). Effects of metacognitive strategies on problem solving ability in construction education. Direct access:http://www.ascpro.ascweb.org.

Kuntjoyo, (2009). Metakognisi dan keberhasilan peserta didik. Direct access:http://www.ebekunt.wordpress.com/2009/.../metakognisi-dankeberhasilan_peserta_didik.

Kuzle, A. (2011). Patterns of metacognitive behavior during mathematics problem solving in a dynamic Geometry environment. Direct access: http://www.jwilson.coe.uga.edu,

Lioe, L.T., Fai H. K. \& Hedberg, J.G. (2006). Students' metacognitive problem solving strategies in solving open-ended problems in pairs. Direct access: http://www.math.ecnu.edu.cn/.../tsg205.doc.

Livingstone, J.A. (1997). Metecognition on overview. Direct access:http:// www. gse.buffaloedu/fas/shuell/cep564/Metacog.htm.

Magiera, M. T. \& Zawojewski, J. S. (2011). Characterizations of social-based and self-based contexts associated with students' awareness, evaluation, and regulation of their thinking during small-group mathematical modeling. Journal for Research in Mathematics Education. Number 5, Volume 42 November 2011. pp. 486-516.

Mariam, A. M. \& Idrus, N. M. (2013). Metacognitive strategies in quadratic equation word problem. Jurnal Pendidikan Sains dan Matematik Malaysia. Volume 3 Number 2 ISSN 2232-0393. Direct access: http://www .pustaka2.upsi.edu.my/.../-metacognitive.

Marrongelle, $K$. (2007). The role of physics in students' conceptualization of calculus consepts: Implications of research on teaching practice. Direct access, http://www.Math.Uoc.Gr/ Ictm2/Proceedings/Pap153.Pdf.

Mokos, E. \& Kafoussi, S. (2013). Elementary students' spontaneous metacognitive functions different types of mathematical problems. Journal Research in Mathematics Education. Volume 2 number 2, June 2013. pp 242-267. Direct access: http://www.hipatiapress.com.

Peraturan Menteri Pendidikan dan Kebudayaan Republik Indonesia Nomor 54 Tahun 2013 tentang Standar kompetensi lulusan pendidikan dasar dan menengah.

Peraturan Menteri Pendidikan dan Kebudayaan Republik Indonesia Nomor 69 Tahun 2013 tentang Kerangka dasar dan struktur kurikulum sekolah menengah atas/madrasah aliyah.

Peraturan Menteri Pendidikan dan Kebudayaan Republik Indonesia Nomor 24 tahun 2016 tentang Kompetensi inti dan kompetensi dasar pelajaran pada kurikulum 2013 pada pendidikan dasar dan menengah.

Purnomo, D., Nusantara, T., Subanji, Raharjo, S. (2016a). The Characterization of mathematics students' metacognition process in solving mathematical problems. Article presented at 3rd International Conference on Research, Implementation, and Education of Mathematics and Science (ICRIEMS) 2016. May 16th-17th Yogjakarta State University (UNY).

Purnomo, D., Nusantara, T., Subanji, Rahardjo, S. (2016b). Metacognition process characteristics of the students in solving mathmatics problems. IOSR Journal of Research \& Method in Education (IOSR-JRME) e-ISSN: 2320-7388,p-ISSN: 2320-737X Volume 6, Issue 5 Ver. III (Sep. - Oct. 2016), pp.26-35 DOI: 10.9790/7388-0605032635. 
Purnomo, D., Nusantara, T., Subanji, Rahardjo, S. (2017), The characteristic of the process of students'metacognition in solving Mathematics problems. International Educational Studies (IES) Journal. ISSN 1913-9020 E-ISSN 1913-9039. Volume 10, Number 5.

Sabella, M.S. \& Redish E.F. (2003). Student understanding of topics in calculus. Direct access:http://www.physics.umd.edu/perg-/plinks/calc.htm.

Schoenfeld, A. H. (1992). Learning to think mathematically: problem solving, metacognition, and sensemaking in mathematics. Direct access: http://www.math.ubc.ca.

Schoenfeld. A.H., Elizabeth \& Corner, E. (1992). Learning to think mathematically: problem solving metacognition, and sensemaking in mathematics. Berkeley, CA. Reston: NCTM

Schoenfeld, A. H. (1994). Mathematical thinking and problem solving. New Jersey: School Mathematics. Reston: NCTM

Sengul, S. \& Katranci, Y. (2012). Metacognitive aspects of solving function problems. Procedia-Social and Behavioral Sciences 46 ( 2012 ) 2178 - 2182. Directaccess: http://www.sciencedirect.com/science/article/pii/S18770-42815042068.

Stillman, G. A. \& Galbraith, P. L. (1998). Applying mathematics with real world connections: Metacognitive characteristics of secondary students. Educational Studies in Mathematics 36(2), 157-195.

Tan, O. S. (2004). Cognition, metacognition, and problem-based learning, in enhancing thinking through problem-based learning approaches. Singapore: Thomson Learning.

Veenam, M.V.J., Wilhelm, P. \& Beishuizen, J. J. (2004). The relation between intellectual and metacognitive skills from a developmental perspective. Direct access: http://www.ww4.ncsu.edu/.../Veenman,\%20Wilhelm ,\%20\%26\%20-Beishuizen\%2004.pdf.

Wilson, J. (1997). Beyond the basics: Assessing students' metacognition. Paper Presented at the 14th Annual Hong Kong Educational Research Association Conference. Hong Kong. November, 1997. Direct access: http://www.files .eric.ed.gov.fulltext/ED415244.pdf.

Wilson, J. \& Clarke D. (2002). Monitoring mathematical metacognition. Paper presented at the Anual Meeting for the American Education Research Assosiation, New Orleeans, LA

Wilson, J. \& Clarke D. (2004). Towards the modelling of mathematical metacognition. Mathematics Education Research Journal. 16(2) pp. 25-48. Direct access: http://www.files.eric.ed.gov/fulltext/EJ747867.

Wong Khoon Yoong; (2007). Metacognitive awareness of problem solving among primary and secondary school students. Direct access: $h t t p: / / w w w$.math. nie.edu.sg.

Zainal, Z. \& Tajudin, N. M. (2013). Metacognitif process in solving non-routin mathematics problems. Direct access: http://www.psmm.upsi.edu.my.

Zechmeister, E.B. \& Neyberg, S.E. (1982). Human memory: An introduction to research and theory. Monterey, C.A: Brooks/Cole Publishing Company. 